Ethiopian Journal of Environmental Studies \& Management 9(4): 470 - 480, 2016.

ISSN:1998-0507

Submitted: March 28, 2016

doi: http://dx.doi.org/10.4314/ejesm.v9i4.7

Accepted: July 14, 2016

\title{
ASSESSMENT OF MORPHOLOGICAL AND HYDROLOGICAL PARAMETERS OF OYUN RIVER BASIN, NIGERIA
}

\section{ABDULKADIR, TAOFEEQ SHOLAGBERU}

Department of Water Resources and Environmental Engineering, University of Ilorin, P.M.B. 1515, Ilorin, Nigeria

Email: abdulkadirts4u@gmail.com

\begin{abstract}
The study involves evaluation of basin area, slopes, shape of the basin as morphological parameters and analysis of flow frequencies for flood and low flows, developing unit hydrograph and analysis of rainfall intensity distribution in the study area as hydrological parameters. The morphological analysis of the basin yielded basin area, slope, elongation and circulatory ratio of $830 \mathrm{~km}^{2}, 0.57 \%, 0.46$ and 0.35 respectively. For hydrological analysis, flow frequency, unit hydrograph and rainfall analysis were evaluated. The flood (peak) and low flows were fitted with Gumbel Extreme Value Type I \& III model, and the recurrence intervals for low and peak flows of $0.0004 \mathrm{~m}^{3} / \mathrm{s}$ and $3.5772 \mathrm{~m}^{3} / \mathrm{s}$ were obtained as 4 and 44 years respectively. The mean annual maximum flow and mean annual runoff depth were estimated to be $7.97 \mathrm{~m}^{3} / \mathrm{s}$ and $6.5 \mathrm{~mm}$ respectively. This showed that the intensity of rainfall contributing to the volume of river discharge was $6.5 \mathrm{~mm} /$ day. Unit hydrograph was developed for the river basin using SCS approach. More so, rainfall analysis was carried out to determine the flood and drought periods. The results indicated that Oyun river basin is relatively small watershed with elongated narrow shape and nonsteep slope which contributed to relatively slower draining of water into the river. From the analysis, flooding is expected in the month of September while drought may be expected in the months of December to February. The results of this study will be useful to river basin managers in managing and planning of water resources and facilities development.
\end{abstract}

Key Words: Hydrological, Morphological, River basin, SCS, Flood, Low flow

\section{Introduction}

The development of water resources necessitates the study of complexity of the water system for adequate utilization, maintenance and management of the system. The study encompasses the occurrence, distribution, movement and properties of water on earth and their relationship with environment within each phase of hydrological cycle. Thus hydrologists are involved in planning, analysis, design, construction, maintenance and operation of projects for the control, utilization and management 
of water resources (Wanielista et al., 1997). The required hydrometric information about the watersheds or basins which are required by hydrologists are gathered through measurement of hydrological, morphological and metrological parameters. In many cases, these are not readily available for mostly small watersheds. In such situations, rainfall information may be combined with rainfall-runoff models to obtain some other information. Hydrological events are important factors in water resource and fisheries management. In particular, streamflow variability and availability can affect stream biota at different life stages during the year (Caissie, 2000). High flows resulted to flooding of downstream areas while the low flows affect fish movement, stream water temperature and causes drought. Hydrologic characteristics of basin are evaluated to provide basis for stormwater management and to protect streams from increased erosion and flooding, and to help determine the basin management plans for critical areas (Dave, 2008).

River morphology can be explained by channel patterns and forms, and is affected by factors such as discharge, water surface slope, water velocity, depth and width of the channel, and river bed materials (Iware, 2004). Morphological assessment of a river involves evaluation of geometry of the river basin and how they respond to a number of processes and environmental conditions over period of time. Factors such as diversion of flow to and from channels, storage of water in reservoirs and increased use of ground water have been discussed in many literatures to have affected the distribution and timing of streamflow and transportation of sediments. Also, hydrodynamic effects like wave, flow, sediment load and tides of the coastal areas arising out of the river constitutes direct and very significant changes in the structures of the rivers. All these factors have contributed to changes in channel geometry and consequently affect the hydrological balance. River channels and its major tributaries undergo major changes in hydrologic regime and morphology when the water resources of the basin began to be developed for agricultural, municipal and industrial uses (Mare, 2007). Horton (1945) reported that morphological changes can be effectively analyzed by the use of satellite imageries of the river basins of different years. In order to increase our understanding on watershed geometry as it affects streamflow variability and availability, this study is aimed at assessing the hydrological (discharge) and morphological (geometry) characteristics of Oyun river basin, Kwara State, Nigeria.

\section{Study Area}

The Oyun local government area is located south east of Ilorin, Kwara State. The area has an open undulating land scope with occasional rocky outcrops in the north western part with varying slopes. The area falls within the broad region of Nigeria known as grass plains where the land is heavily farmed with just a very limited area of forest reserve. Oyun river basin, the study area, has an estimated terrain elevation above sea level of $259 \mathrm{~m}$ and is located between latitude $9^{0} 50^{1}$ and $8^{0} 24^{1}$ north and longitude $4^{\mathrm{o}} 38^{1}$ and $4^{0} 03^{1}$. It originates at an elevation of $465.003 \mathrm{~m}$ close to Ila Oragun and flow in an approximately northeast direction for about $80 \mathrm{~km}$ before joining river Asa (Mustafa and Yusuf, 
2012). River Oyun is the main source of water to Offa town and its neighbours and also the main sources of raw water to university of Ilorin water supply scheme. Figure 1 shows map of Oyun river basin with network of rivers and its catchment areas. The catchment area under consideration is enclosed within the thick black boundary line as indicated in the
Figure. River Oyun along with Asa and Weru rivers are the three main tributaries of river Awun with flows in a northwest direction for about $70 \mathrm{~km}$ from the confluence of river Asa and Oyun and in the northeast direction for another $22 \mathrm{~km}$ before discharging into river Niger upstream of Jebba hydroelectric dam, at an elevation of $76 \mathrm{amsl}$.

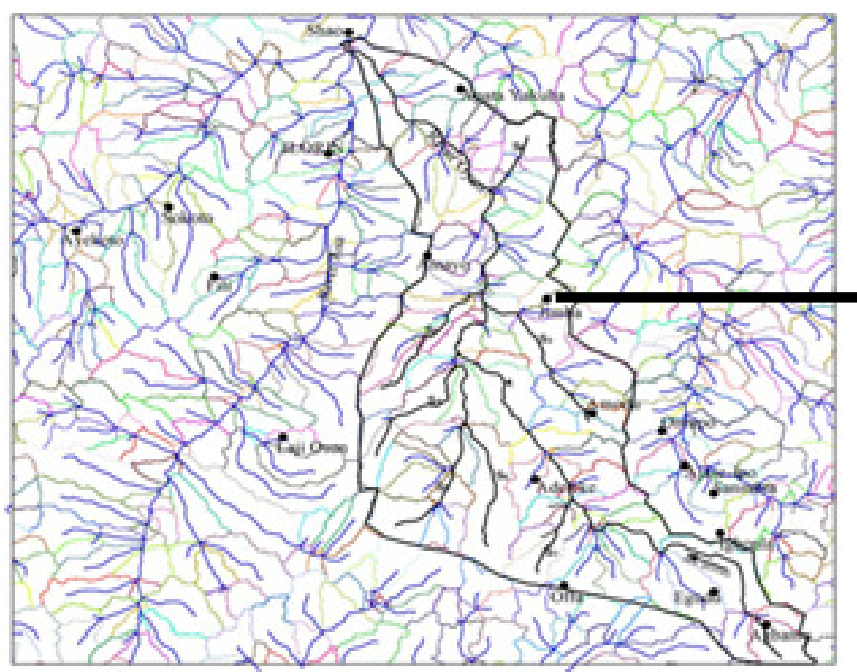

(a) Oyun River Basin

Figure 1: Map of Nigeria and Oyun River Basin

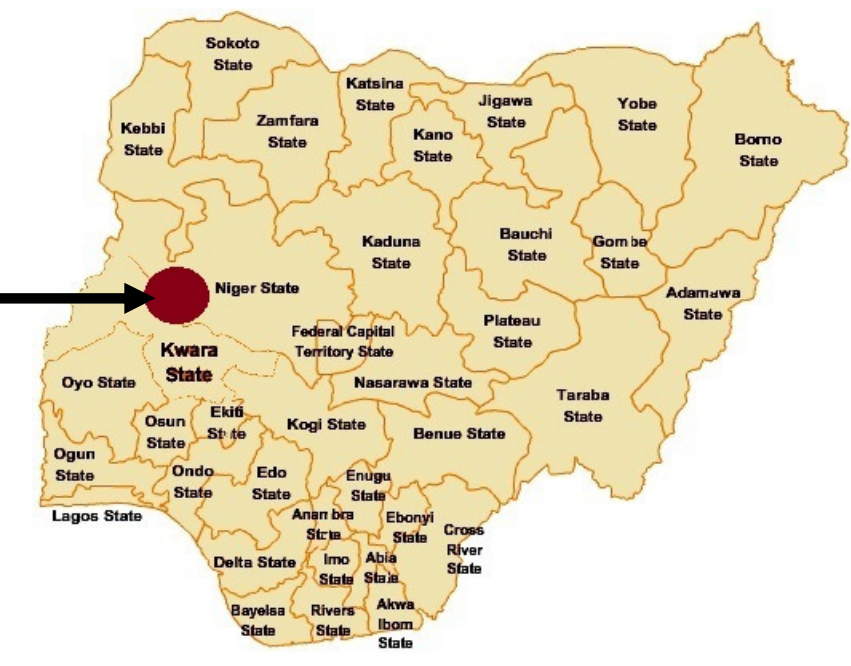

(b) Map of Nigeria

\section{Materials and Methods}

The required data for the assessment of morphological and hydrological characteristics of the study area are rainfall and river discharge data which were obtained from Nigeria Metrological Agency, (NIMET) for the periods of (1989-2013) and (1972-2014) respectively. The topographical map of the study area was obtained from Lower Niger River Basin Authority, Ilorin, Kwara State. In the morphological analysis, topographic map of the study area was digitized using Global Mapper and AutoCAD 2010 to analytically obtain watershed parameters. Some of the parameters are watershed area, average channel slope, maximum relief, length of the main river, perimeter of the basin, maximum basin length, elongation ratio, circulatory ratio and slope factor. In order to compute average channel slope, the entire basin was divided into a number of different distributaries along the river channel marked $S_{1}, S_{2}$ to $S_{n}$. The inlet and discharge elevations were obtained from Global Mapper for each tributary. Slopes for each tributary were computed and the average value was obtained.

Hydrological assessment of watershed under consideration will be limited to flow characteristics assessment, development of unit hydrograph and finally evaluation of 
rainfall-duration-frequency for the study area. A monthly flow data of 43 years (1972 - 2014) was used for the assessment of flow characteristics and statistically analysed to infer some useful information. Gumbel Extreme Value Type I \& 111 probability distribution function was used in fitting the high and low flow periods and their return periods are evaluated. The mean annual runoff depth was also evaluated using an empirical equation. Also method of soil conservation service (SCS) was adopted for the development of unit hydrographs for estimation of basin parameters such as peak discharge, lag time, time of concentration, etc. Rainfall data for a period of 25 years (1989 2013) was statistically analysed and design storm for different recurrence intervals (such as 10, 20, 50, 100 and 200

$$
\text { mean annual runoff }(\mathrm{mm} / \text { day }), Q_{d}^{\prime}=\frac{\text { mean annual flow }\left(\frac{\mathrm{m}^{2}}{\mathrm{~s}}\right)}{\text { guage basin area }\left(\mathrm{Km} \mathrm{m}^{2}\right)} \times 86.4
$$

For flow frequency analysis, annual flood and low flow records are fitted to statistical distribution functions to estimate the T-year events for such to reoccur. There are four different models usually used which are three parameters lognormal, Type I Extremal, Log-Pearson Type 111 distribution and Partial duration series analysis. The first three distribution functions are usually used for high flow events based on historical annual flood observations while the partial duration series analysis used daily discharge records to estimate flood values (Caissie, 2000). The model used in this study is Gumbel Extremal type I \& III distribution expressed as follows in Equations 2a, 2b and 2c (Bilewu and Salami, 2009).

\section{Extremal (Gumbel) type I \& III distribution$$
Q_{T}=Q_{a v}+\sigma(0.78 y-0.45)
$$

years) was analysed using Gumbel Extremal probability distribution for maximum rainfall intensity.

\section{Hydrological Study}

In hydrological assessment, a number of statistical parameters are of interest for determining flow characteristics such as mean annual, median, range, minimum, maximum, standard deviation and coefficient of variation of flow. The annual maximum flow for basins can be used to determine the annual runoff characteristics in ( $\mathrm{mm} /$ day) as given in Equation 1 (Sule et al., 2011). This makes it possible to compared precipitation to runoff in the watershed. This is subsequently used to determine the peak flow for the river.
Where $y=-\ln \left(-\ln \left(1-\frac{1}{T}\right)\right)$, for type I (2b)

$y=-\ln \left(-\ln \left(\frac{1}{T}\right)\right)$, for type III

$Q_{T}=$ reoccurrence interval for a flow at return period $\mathrm{T}, Q_{a v}=$ mean of the flow record and $\sigma=$ standard deviation.

In many hydrologic design projects, the first step is the determination of the rainfall event to be used for the intensity duration frequency (IDF) analysis. The rainfall events are hypothetical and usually termed the design storm events (John and Gribbin, 2006). The most common approach of determining this involves establishing the relationship between rainfall intensity, duration and the frequency (or return period). If rainfall data are available, IDF curves can be developed using frequency analysis as defined in many literatures. 
To develop dimensionless unit hydrograph for drainage areas of varying sizes and different locations, soil conservation service (SCS) method is usually adopted. The estimated values for both the peak discharge and time to peak are applied to the dimensionless hydrograph ratios (Viessman et al., 1989). In accordance to this method, points for the unit hydrograph are obtained and used to develop the unit hydrograph curves (Arora, 2004). The peak discharge are expressed as shown in Equation 3.

$$
Q_{p}=\frac{0.200 Q_{\pi} A}{t_{p}}
$$

Where $Q_{p}=$ Peak discharge $\left(\mathrm{m}^{3} / \mathrm{s}\right) ; A$ $=$ Drainage area $\left(\mathrm{km}^{2}\right) \mathrm{Q}_{\mathrm{d}}=$ Quantity of

runoff $(\mathrm{mm})$ and $t_{\mathrm{p}}=$ Time to peak (hour).

The following expressions in Equations $4-8$ were reported necessary in literatures in developing unit hydrograph.

$$
t_{p}=\frac{D}{2}+t_{L}
$$

Where $t_{p}=$ time to peak (hour), $\mathrm{D}=$ duration of rainfall (hour), $t_{L}=$ lag time (hour)

$$
\begin{aligned}
& \mathrm{D}=0.133 \mathrm{t}_{\mathrm{c}} \\
& t_{2}=0.6 \mathrm{t}_{\mathrm{e}}
\end{aligned}
$$

Where $t_{c}=$ the time of concentration (hours) and it is defined by Equation 9.

$$
t_{\sigma}=0.0195 L^{0.775} S^{-0.385}
$$

Where $t_{c}=$ Time of concentration (min), $\mathrm{L}=$ Length of main river $(\mathrm{m}), \mathrm{S}=$ Watershed gradient or slope. The watershed slope can be described as in Equation 11.

$$
s=\frac{\text { Differene in elevation along the flow path }}{\text { maximum length of flow }}=\Delta E / L
$$

\section{Morphological Assessment}

Geomorphologic characteristics of watershed as explained by Horton (1945) are systematic description of watershed geometry and its stream network system, measurement of linear aspects of drainage network, aerial aspects of drainage basin and relief of channel network. For ungauged channels, measurement of channel morphology gives indirect estimates of discharge, which, if varying with time, may indicate changes in mean discharge Osterkamp and Schumm, 1996). Stream flow and sediment deposition pattern along channel determines its shapes. Therefore, stable streams are those that, over time, maintain stable morphology, constant pattern (sinuosity), slope and crosssection (Osterkamp and Schumm, 1996). Some of basic watershed characteristics as highlighted in the literatures are drainage area (A), watershed length (L), slope $(\mathrm{S})$, shape, Length to the centre of area $\left(L_{c}\right)$. Others are shape factor $\left(\mathrm{L}_{1}\right)$, circulatory ratio $\left(\mathrm{R}_{\mathrm{c}}\right)$ and elongation ratio $\left(\mathrm{R}_{1}\right)$ defined by Equations 9, 10 and 11 respectively.

$$
\begin{aligned}
& \left(\mathrm{L}_{1}\right)=\left(\mathrm{L}^{*} \mathrm{~L}_{\mathrm{c}}\right)^{0.3} \\
& \boldsymbol{R}_{\varepsilon}=A / A_{c} \\
& \boldsymbol{R}_{1}=D_{c} / L_{b m}
\end{aligned}
$$

Where $A_{c}=$ area of circle having equal perimeter as the perimeter of drainage basin, $D_{c}=$ diameter of a circle having same area as the basin to the maximum basin length $\left(\mathrm{L}_{\mathrm{bm}}\right)$. Other basin morphological parameters are estimated using the empirical equations while some are measured directly from the 
topographical maps in Global mapper environment.

\section{Results}

\section{Basin Morphological and Hydrological} Assessment

The basin morphology was assessed using Global Mapper and AutoCAD 2010 to digitize the topographic map of the study area in order to extract watershed morphological parameters. In determining the average channel slope, the entire basin was divided into seven
(7) different distributaries marked $S_{1}, S_{2}$ to $S_{7}$ as indicated in Figure 1. The inlet and discharge elevations were obtained from Global Mapper for each tributary. Slopes for each tributary were computed and the average value was obtained as presented in Table 1. The average channel slope was estimated to be 0.0057 . Summary of the other results obtained from the computation of the watershed parameters is presented in Table 2.

Table 1: Length and elevations for each distributory

\begin{tabular}{rrrrl}
\hline Tributary & \multicolumn{1}{l}{$\begin{array}{l}\text { Length } \\
(\mathrm{m})\end{array}$} & $\begin{array}{l}\text { Inlet elevation, } \\
\mathrm{E}_{1}(\mathrm{~m})\end{array}$ & $\begin{array}{l}\text { Discharge } \\
\text { elevation, } \mathrm{E}_{2}(\mathrm{~m})\end{array}$ & Slope, Si \\
\hline 1 & $5,901.76$ & 341.257 & 293.078 & 0.0082 \\
2 & $13,472.36$ & 374.020 & 312.321 & 0.0046 \\
3 & $15,005.17$ & 383.852 & 315.533 & 0.0046 \\
4 & $13,494.21$ & 435.421 & 325.057 & 0.0082 \\
4 & $18,324.48$ & 423.722 & 328.598 & 0.0052 \\
6 & $12,203.31$ & 404.211 & 343.960 & 0.0049 \\
7 & $7,588.49$ & 402.547 & 368.372 & 0.0045 \\
\hline
\end{tabular}

Table 2: Summary of the results obtained for basin characteristics.

\begin{tabular}{lll}
\hline S/No & Watershed Parameters & Estimated Values \\
\hline 1 & Watershed Area $(\mathrm{A})$ & $* 830 \mathrm{~km}^{2}$ \\
2 & Watershed Slope $\left(\mathrm{S}_{\mathrm{c}}\right)$ & 0.0057 \\
3 & Average channel slope & 0.00246 \\
4 & Maximum Relief & $205.358 \mathrm{~m}$ \\
5 & Length of the main river & $* 83.750 \mathrm{~km}$ \\
6 & Length along the main channel from & \\
& the outlet to a channel point nearest & \\
& the watershed centroid $\left(\mathrm{L}_{\mathrm{c}}\right)$ & $* 43.845 \mathrm{~km}$ \\
7 & Perimeter of the river basin & $172.5 \mathrm{~km}$ \\
8 & Maximum basin length & $70 \mathrm{~km}$ \\
9 & Elongation ratio & 0.46 \\
10 & Circulatory ratio & 0.35 \\
11 & Shape factor & 11.735 \\
\hline
\end{tabular}

*Parameters measured directly from the map using Global Mapper Tool 
The basin hydrological characteristics are assessed through flow characteristics in the watershed, estimation of basin parameters through unit hydrograph development and rainfall analysis of the study area. The flow characteristics analysis was conducted with 43 years flow data (1972 - 2014). The mean annual flow for the period of record was $7.97 \mathrm{~m}^{3} / \mathrm{s}$. The mean and standard deviation for the period of high flow are $1.822 \mathrm{~m}^{3} / \mathrm{s}$ and 0.705 respectively. While for low flow are $0.053 \mathrm{~m}^{3} / \mathrm{s}$ and 0.077 respectively. Gumbel Extreme Value Type I \& 111 probability distribution function was used to fit the high and low flow periods respectively in order to predict its values for various return periods. The annual maximum and minimum discharges were separated for high and low flows analysis respectively. The low and high flows were obtained to be $0.0004 \mathrm{~m}^{3} / \mathrm{s}$ and $3.5772 \mathrm{~m}^{3} / \mathrm{s}$ with respective return periods estimated at about 4 and 44 years. This implies that a minimum flow equivalent in magnitude to $0.0004 \mathrm{~m}^{3} / \mathrm{s}$ is likely to occur after a period of about 4 years. While peak flow of $3.5772 \mathrm{~m}^{3} / \mathrm{s}$ is likely to occur after about 44 years. The mean annual runoff depth was obtained as $6.5 \mathrm{~mm} / \mathrm{day}$.

In developing unit hydrograph for Oyun river basin in order to obtain some hydrological basin parameters, SCS method was adopted. The parameters' values obtained for $t_{c}, D, t_{L}, t_{p}$ and $Q_{p}$ were $15.53 \mathrm{hrs}, 2.07 \mathrm{hrs} 9.318 \mathrm{hrs}$, $10.35 \mathrm{hr}$ and $108.42 \mathrm{~m}^{3} / \mathrm{s}$ respectively. The watershed characteristics required for generation of a unit hydrograph as estimated and obtained from the topographic map of the River catchment under consideration are presented in Table 3 .

Table 3: Parameters for the generation of unit hydrograph for Oyun river

\begin{tabular}{|l|l|l|l|l|l|l|l|l|}
\hline Basin parameters & $\mathrm{L}(\mathrm{km})$ & $\mathrm{t}_{\mathrm{l}}(\mathrm{hr})$ & $\mathrm{D}(\mathrm{hr})$ & $\mathrm{t}_{\mathrm{c}}(\mathrm{hr})$ & $\mathrm{t}_{\mathrm{p}}(\mathrm{hr})$ & $\mathrm{Q}_{\mathrm{p}}\left(\mathrm{m}^{3} / \mathrm{s}\right)$ & $\mathrm{A}\left(\mathrm{km}^{2}\right)$ & $\mathrm{S}(\%)$ \\
\hline Values & 83.750 & 9.317 & 2.065 & 0.155 & 10.350 & 108.420 & 830.000 & 0.570 \\
\hline
\end{tabular}

The calculated values for parameters $t_{p}$ and $Q_{p}$ were applied to the SCS dimensionless unit hydrograph to obtain the corresponding unit hydrograph ordinates. The generated unit hydrograph for the basin is as shown in Figure 2.

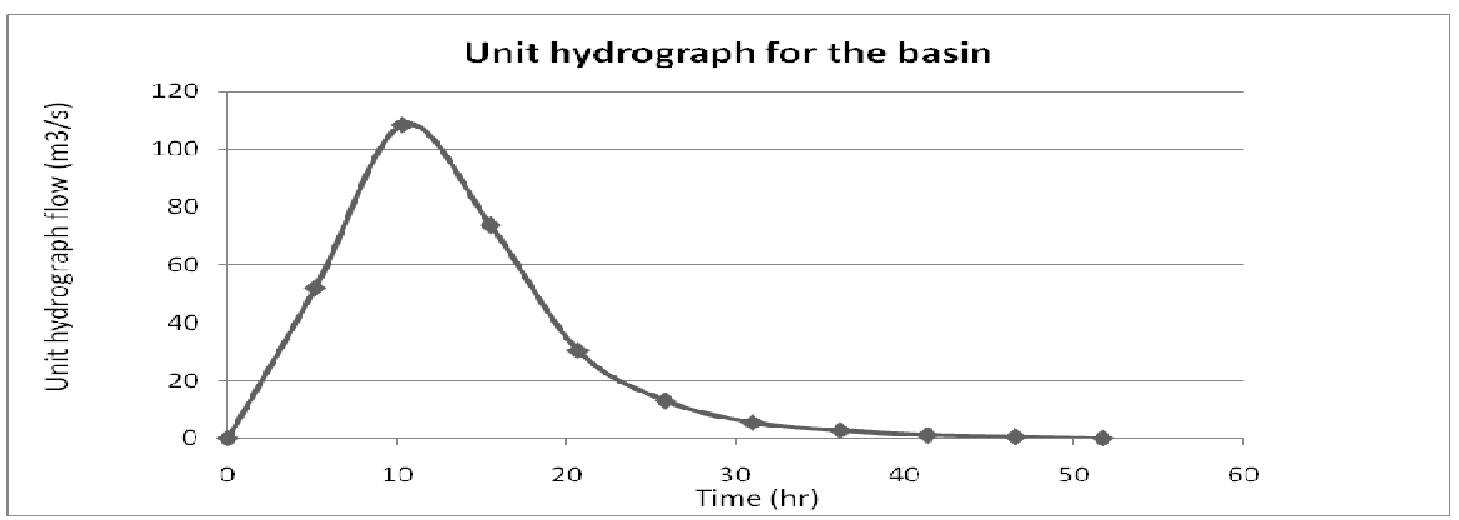

Figure 2 Unit hydrograph for the river basin 
Intensity duration frequency analysis was carried out with 25 years (19892013) rainfall data. The annual mean values for the period of record and standard deviation are $269.847 \mathrm{~mm}$ and 64.34 respectively. For the design storm duration of 24 hours, the return periods for different recurrence intervals were selected to be 10, 20, 50, 100 and 200 years. By applying Gumbel Extremal probability distribution for maximum rainfall intensity for different recurrence interval, the results are as presented in Table 5. The average rainfall intensity was estimated for the different durations and return periods and the intensity duration curve is presented in Figure 3.

Table 5: Rainfall depth for the selected return periods

\begin{tabular}{lll}
\hline Return periods (T) in years & $y=-\ln \left(-\ln \left(1-\frac{1}{T}\right)\right)$ & $Q_{T}=269.847+64.34(0.78 y-0.45)(\mathrm{mm})$ \\
\hline 10 & 2.25 & 358.80 \\
20 & 2.97 & 389.94 \\
50 & 3.9 & 436.62 \\
100 & 4.6 & 471.75 \\
200 & 5.3 & 506.88 \\
\hline
\end{tabular}

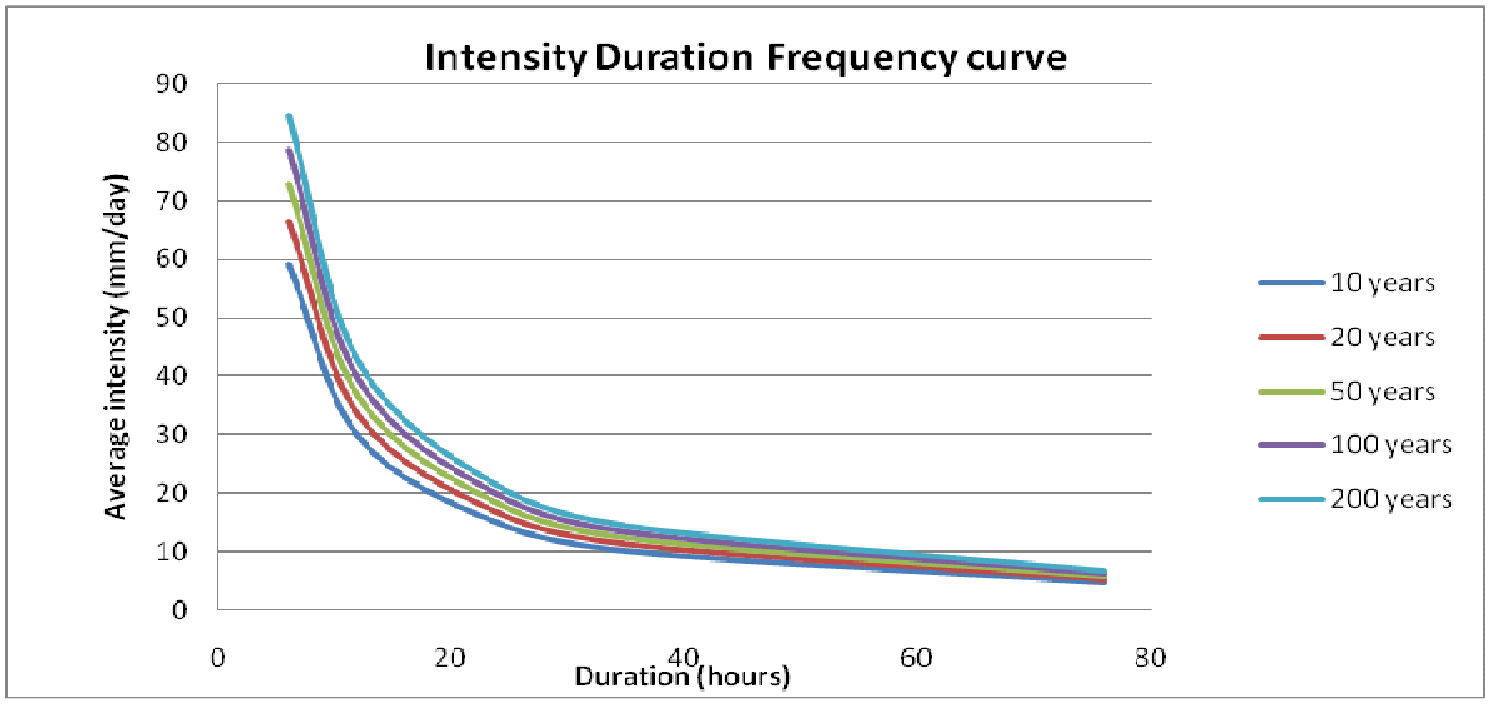

Figure 3 Intensity duration frequency curves

\section{Discussion}

Morphological assessment was carried out on Oyun river basin to determine the size and topographical features of the basin and how it affects the hydrological characteristics of the basin. The estimated drainage area of approximately $830 \mathrm{~km}^{2}$ showed that it is a relatively small watershed and water will take little time to drain into the river, resulting in a short lag time with respect to drainage area. The basin slope was estimated by considering the inflow and outflow elevations difference for sub- 
basins within the river basin. Then, slope for each sub-basin were computed and the average basin slope value was estimated to be $0.57 \%$. This indicates that the basin slope is not very steep and is an open undulating landscape. The maximum relief for the basin was estimated to be $205.358 \mathrm{~m}$ by considering the highest and the lowest elevations of the watershed. The shape factor, which is dimensionless, represents the ratio between the square of basin length to the basin area (UNESCO, 2011) and estimated as 11.7 which is greater than 1.0. This indicates that the basin is long narrow drainage basin. The circulatory ratio for the basin was obtained as 0.35 (which is less than 1.00) indicating that basin is not circular in shape according to UNESCO (2011) classification. Also, the elongation ratio that relates the ratio of diameter of a circle having the same area as the drainage basin to the maximum basin length was obtained as 0.46 indicating that the basin is relatively elongated. However, this is contrary to the results of a study carried out in India by Patil et al. (2015) using GIS and remote sensing techniques to estimate elongation ratio as 0.7844 and concluded that the watershed is less elongated as the values approaches 1.00. These parameters highlighted the morphological characteristics of the river basin that determine the hydrological behaviours of the basin. Considering the circulatory ratio to the elongation ratio, shape factor and slope, it was inferred that the basin is more elongated, narrow and not very steep in slope. Thus, water takes relatively longer time to reach the river with respect to steepness of the slope.

In assessing the hydrological characteristics of Oyun river basin, flow characteristics was evaluated, rainfall intensity distribution was evaluated and unit hydrograph was developed. The annual flow characteristic of the river showed its behaviour in term of discharge over the years. In this study, monthly flow data was used and the annual minimum and maximum flow over the period of record (1976-2014) were used to examine the annual peak (flood) and least (low) flow characteristics of the river respectively. Flow frequency analysis shows the time interval before the next occurrence for any particular quantity of discharge. Gumbel Extremal method of analysis was used to predict the time interval for the highest and lowest flows of the river over the years of record to re-occur. The highest flow was $3.5772 \mathrm{~m}^{2} / \mathrm{s}$ which occurred in the month of September 1988 and the lowest flow was $0.0004 \mathrm{~m}^{3} / \mathrm{s}$ in January 1981 . Observing the flow record, September has the highest mean flow for the period of record of about $1.55 \mathrm{~m}^{3} / \mathrm{s}$ while January has lowest mean flow of $0.108 \mathrm{~m}^{3} / \mathrm{s}$. From the frequency analysis, it will take about 4 and 44 years respectively to have minimum and maximum flows of about $0.0004 \mathrm{~m}^{3} / \mathrm{s}$ and $3.5772 \mathrm{~m}^{3} / \mathrm{s}$ respectively to reoccur in the watershed. In many studies, it has been reported that intensity and amount of rainfall highly affect the river discharge if rainfall is its major source. Thus, high rainfall signifies high runoff and subsequently high river discharge. In the area under consideration, the mean annual maximum flow for the river and mean runoff characteristic were estimated to be $7.97 \mathrm{~m}^{3} / \mathrm{s}$ and $6.5 \mathrm{~mm}$ respectively. This showed that the intensity of rainfall over the basin contributing to the volume 
of the river discharge was $6.5 \mathrm{~mm}$ per day.

SCS method was adopted to develop unit hydrograph for the basin. The peak discharge and time to peak were obtained from Figure 2 as $108.4 \mathrm{~m}^{3} / \mathrm{s}$ and 10.35hours respectively. This is useful in planning for flood situations and time of drought as they show discharge that originated from precipitation. Rainfall data was used in assessing rainfall frequency distribution, though, rainfall data for 1972 to 1981 were not available. It was observed from the period of record that September is always having the maximum rainfall with average of about 232.33mm per year. However, December has the minimum of about $7.66 \mathrm{~mm}$ followed by February and subsequently January with average rainfall of $14.45 \mathrm{~mm}$ and $19.88 \mathrm{~mm}$ respectively. The reoccurrence intervals for different return periods were evaluated using Gumbel Extremal probability function. The rainfall intensity for the said reoccurrence intervals were as reported in Table 5. It was observed that rainfall intensity increases as the period increases. The average intensity was obtained for the different reoccurrence intervals over different time durations as shown in Figure 3. This rainfall intensity distribution is significant in flood prediction for the design of water management infrastructure since it shows the amount of rainfall that can accumulate over certain duration.

\section{Conclusion}

The analysis of the morphological parameters showed that Oyun river basin is a relatively small watershed with an undulating landscape, elongated, narrow and not very steep in slope, thus water takes relatively longer time to reach the river. The hydrological assessment of the basin indicated that the volume of rainfall that contributes to runoff is relatively small compared to the total rainfall. This could be as a result of high evapotranspiration losses within the watershed. In addition to this, vegetation might also prevent adequate runoff by intercepting precipitation and adding to the rate of evaporation. Therefore, it can be deduced that the size, shape and other morphological parameters of the basin contribute to hydrological characteristics of the river basin. The analysis also showed that September is having the highest amount of rainfall and subsequently high stream discharge. Thus, flooding is expected in the month of September while drought may be expected in the months of December to February since they are having minimum precipitation values. The results of this study will be useful to river basin managers for resources management, planning, facilities development and hazards prevention.

\section{References}

Arora, K.R. (2004). Irrigation, Water Power and Water Resources Engineering. Standard Publishers Distributions; 1705-B, NAI SARAK, Delhi, 79-106.

Bilewu, S.O. and Salami, A.W. (2009). Determination of Peak Stream Flows of Different Storm Durations and Return Periods for River Asa Catchment in Ilorin, Nigeria. International e-Journal of Egyptian Engineering Mathematics: Theory and Application, 7: 45-58. 
Caissie, D. (2000). Hydrology of the Petitcodiac River Basin in New Brunswick, Canadian Technical Report of Fisheries and Aquatic Sciences 2301, Department of Fisheries and Oceans Gulf Fisheries Centre, Science Branch Diadromous Fish Division.

Dave, F. (2008). Kalamazoo River Watershed Hydrologic Study. Hydrologic Studies Unit Land and Water Management Division Michigan Department of Environmental Quality, State of Michigan, U.S.A.

Horton, R.E. (1945). Erosional Development of Streams and Their Drainage Basins: HydroPhysical Approach to Quantitative Morphology. Bull. Geol. Soc. Am., 56: 275-370.

Iware, M. (2004). River Morphology and Channel Processes, in Fresh Surface Water, [Ed. James C.I. Dooge], in Encyclopedia of Life Support Systems (EOLSS), Developed Under the Auspices of the UNESCO, Eolss Publishers, Oxford ,UK, [http://www.eolss.net]

John, E. and Gribbin, P.E. (2006). Introduction to Hydraulic and Hydrology with Application for Storm Water Management $3^{\text {rd }}$ Edition; ISBN 1-4180-3295-6.

Mare, H. (2007). Orange River Integrated Water Resources Management Plan. Botswana DWA (Katai, Setloboko) Lesotho, Namibia.

Mustafa, S. and Yusuf, M.I. (2012). A Textbook of Hydrology and Water Resources, Revised
Edition, Topsmerit Page Publishing Co., Abuja, Nigeria.

Osterkamp, W.R. and Schumm, S.A. (1996). Geoindicators for River and River-Valley Monitoring. In Berger, A.R. and Iams, W.J. (Eds). Geoindicators: Assessing Rapid Environmental Changes in Earth systems: 83-100.

Patil, N.P., Kadale, A.S. and Mhetre, G.S. (2015), Assessment of Morphometric Characteristics of Karwadi-Nandapur Micro Watershed Using Remote Sensing and Geographical Information System, International Journal of Scientific \& Technology Research, 4(4): 175-179.

Sule, B.F., Salami A.W., Bilewu, S.O., Adeleke, O.O. and Ajimotokan, H.A. (2011). Hydrology of River Oyun and Hydropower Potential of Unilorin Dam, Ilorin, Kwara State, Nigeria. New York Science Journal. 4(1):69-78. (ISSN: 15540200).

UNESCO (2011). Significance of Geomorphic Analysis of Watershed for Optimization of Recharge Structures, Global Hydrogeological SolutionsUNESCO, New Delhi, Bal Vikas Prakashan Pvt. Ltd, India.

Viessman, W., Knapp, J.W. and Lewis, G.L. (1989) Introduction to Hydrology, Harper and Row Publishers, New York. 149 - 355.

Wanielista, M., Kersten, R. and Ealgin, R. (1997). Hydrology - Water Quantity and Quality Control, 2nd Edn., John Wiley \& Sons, Inc., New York, ISBN 0-471-67259-1. 